\title{
Honey mesquite transpiration along a vertical site gradient
}

\author{
C.J. CUOMO, R.J. ANSLEY, P.W. JACOBY, AND R.E. SOSEBEE
}

\begin{abstract}
Authors are research assistant, University of Nebraska, Lincoln; postdoctoral research associate, Texas Agricultural Experimental Station, Vernon 76394; professor, Texas Agricultural Experiment Station. Vernon 76384; and professor, Department of Range and Wildlife Management, Texas Tech University, Lubbock 79409.
\end{abstract}

\begin{abstract}
Honey mesquite (Prosopis glandulosa Torr.) occurs on a variety of sites varying in soil depth and moisture availability. The objective of this study was to compare water use by honey mesquite on upland, lowland, and riparian sites which were assumed to represent increasing levels of available soil moisture within a single watershed. Effects of the upland and lowland sites were evaluated in 1985. The riparian site was evaluated with the other 2 sites in 1986. Soil moisture and average daily transpiration were greater $(P<0.05)$ on the upland than on the lowland site from mid-May to July in both years, and from mid-August through September 1986. These differences were attributed mainly to soil surface characteristics which created greater infiltration on the upland site. The riparian site was near an ephemeral stream and had a water table as shallow as $1.5 \mathrm{~m}$. Soil water content was much greater for this site compared to the other 2 sites throughout 1986. Mesquite transpiration was greater on the riparian site than on the other sites during July 1986, when seasonal vapor pressure deficit was at maximum. However, transpiration was less on the riparian site than on the upland site during May and June 1986. Soil temperature was significantly lower on the riparian than on the upland site and potentially inhibited transpiration on the riparian site in May and June. The study demonstrated a positive relationship between water availability and transpiration by mesquite but did not support the hypothesis that water availability or transpiration was lowest on upland sites.
\end{abstract}

Key Words: Prosopis glandulosa, plant water relations, leaf water potential, stomatal conductance, soil moisture, phreatophyte

Honey mesquite occurs on a variety of sites throughout the southwestern USA and Mexico. In the Sonoran Desert of southern California, where surface water is often limiting, mesquite have deep taproots reaching permanent or semipermanent ground water and respond as phreatophytes (Phillips 1963, Mooney et al. 1977 , Nilsen et al. 1981). In regions where ground water is limiting, mesquite may rely on extensive shallow lateral roots to supply water (Cable 1977, Ludwig 1977, Heitschmidt et al. 1988, Ansley et al. 1990). Mesquite has been described as a facultative phreatophyte which preferentially utilizes shallow soil moisture before deeper moisture (Thomas and Sosebee 1978).

Within the Rolling Plains of northcentral Texas, woody vegetation generally proliferates along riparian drainages. Mesquite, once reported to have been restricted largely to these riparian habitats, has spread in the last century onto adjacent upland sites (Scifres 1980). Little is known concerning relative water use by mesquite along the vertical gradient of a watershed, although some data suggest that water availability and water use may increase

\footnotetext{
The authors wish to express their appreciation to the W.T. Waggoner Estate for the The authors wish to express their appreciation to the W.T. Waggoner Estate for the
use of their ranch, the Brush Control and Range Improvement Association for use of their ranch, the Brush Control and Range Improvement Association for Manuscript accepted 22 August 1991.
}

with deeper soils at lower positions (Easter and Sosebee 1975). Our hypothesis was that transpiration by mesquite would vary along vertical gradients within a watershed. Because soils are generally deeper and there is greater potential for water accumulation at lower positions, transpiration was hypothesized to be greater on these sites than at upper locations. Conversely, lower, more alluvial regions of a watershed tend to have finer textured soils which could potentially reduce soil water availability and thus limit transpiration. Our objective was to compare the influence of site characteristics related to vertical position within a watershed on seasonal patterns of transpiration by honey mesquite.

\section{Materials and Methods}

\section{Study Area}

The study was conductcd within a single watershed located on the W.T. Waggoner Estate, $23 \mathrm{~km}$ south of Vernon, Texas, in Wilbarger County $\left(33^{\circ} 57^{\prime} \mathrm{N}, 99^{\circ} 15^{\prime} \mathrm{W}\right.$; elev. $\left.355-375 \mathrm{~m}\right)$. Mesquite responses were measured on 2 sites, an upland and a lowland, in 1985 and 1986. Response on a third site, termed riparian, was measured in 1986. All 3 sites were within $400 \mathrm{~m}$ of each other, were less than $20 \mathrm{~m}$ different in elevation, and received similar precipitation.

The upland site was located on a ridge near the top of the watershed with southwest exposure and 1 to $3 \%$ slopes. Soils on this site were of the Cosh series of loamy, mixed, thermic, shallow Udic Rhodustalfs (Koos et al. 1962). These were shallow, well drained, moderately permeable soils, formed on weakly cemented sandstone. The A and B horizons extended to $25-\mathrm{cm}$ depth, with sandstone and shale to $170 \mathrm{~cm}$, and shaley clay to $250 \mathrm{~cm}$. Soil texture from $0-30 \mathrm{~cm}$ was sandy loam (68\% sand, $14 \%$ silt, $18 \%$ clay), as determined by the hydrometer method (Bouyoucos 1936).

Soils on the lowland site were fine silty, thermic Fluventic Ustochrepts of the Weswood series. These soils were deep and well drained, with low permeability, formed of calcareous alluvial materials, and had slopes of $0-1 \%$. The $A$ and $B$ horizons extended to $118 \mathrm{~cm}$. We determined soil texture from $0-30 \mathrm{~cm}$ to be sandy clay loam ( $51 \%$ sand, $24 \%$ silt, $25 \%$ clay). The upland site had a more porous soil surface than the lowland site, which had a crusted soil surface (visual observation). A preliminary study determined that infiltration rate was greater on the upland site than on the lowland site, being $13.1 \mathrm{~cm} / \mathrm{hr}$ and $8.4 \mathrm{~cm} / \mathrm{hr}$, respectively.

The riparian site was located near an ephemeral stream at the base of the watershed containing the study (slopes 0-1\%). Soils were of the Mangum series of fine, mixed, thermic, Vertic Ustochrepts. These soils were deep, moderately well drained, very slowly permeable, formed from calcareous alluvial materials. Soil texture from $0-30 \mathrm{~cm}$ was clayey ( $20 \%$ sand, $28 \%$ silt, $52 \%$ clay).

Herbaceous vegetation on the upland site was dominated by purple threeawn (Aristida purpurea Nutt.), hairy grama (Bouteloua hirsuta Lag.), and sideoats grama [ $B$. curtipendula (Michx.) Torr.]. The lowland site was dominated by sand dropseed [Sporobolus cryptandrus (Torr.) Gray]. Dominant herbaceous species on 
the riparian site was little bluestem [Schizachyrium scoparium (Michx.) Nash]. Herbaceous vegetation was more dense on the riparian site than on the other 2 sites.

Woody vegetation on the upland and lowland sites was dominated by honey mesquite with occasional occurrences of lotebrush [Ziziphus obtusifolia (T. \& G.) Gray]. Mesquite canopy cover (estimated by point center quarter method) was between 15 and $20 \%$ on all 3 sites. Mesquite on the riparian site occurred adjacent to a dense stand of riparian trees, dominated by American elm (Ulmus americana L.), and eastern cottonwood (Populus deltoides Bart. Marsh).

\section{Data Collection and Analysis}

Eight trees each on the upland and lowland sites, and 6 trees on the riparian site were sampled for transpiration and stomatal conductance using a Li-Cor LI-1600 steady state porometer (Li-Cor, Inc., Lincoln, Neb. '). Because the objective was to ascertain relative differences among sites, we chose a common reference point for measuring leaf responses on each tree. Leaves on the perimeter of the northeast aspect of each canopy were sampled between 1 and $2 \mathrm{~m}$ from the ground. Measurements were made on the bottom surface of single leaflets of a leaf. Two leaflets, each from a different leaf, were measured (as subsamples) per tree during each sample period for about $1 \mathrm{hr}$ duration, and were pooled prior to mean determination. Measurements were made at 2-hr intervals beginning at 2 and ending at $10 \mathrm{hr}$ after sunrise (about 700 to 1500 hours CST). Diurnal measurements were conducted at 2- to 3-week intervals during the growing season in both years, beginning in mid-May. Three additional trees at each site were sampled for predawn petiole xylem water potential (predawn leaf $\Psi$ ) using a Scholander pressure chamber (Scholander et al. 1965).

Seven aluminum soil water access tubes were installed to a depth of $150 \mathrm{~cm}$ on each site. Volumetric soil water content $(\theta)$ was measured at 30 - and $60-\mathrm{cm}$ depths using a neutron scattering device on each date transpiration was measured. Soil water retention curves were determined at each site and soil depth using a ceramic pressure plate apparatus set at $0.1,0.3,0.5,1.0$, and $1.5 \mathrm{MPa}$ (Richards 1965). Soil matric potential was calculated from $\theta$ using retention curve equations which were extrapolated to $-3.0 \mathrm{MPa}$. Values of $\theta$ and matric potential were pooled over both depths prior to analysis.

Soil temperature was measured between 0530 and 0730 at 30 and $60-\mathrm{cm}$ depths using a single stainless bi-metal thermometer at each site. Air temperature and relative humidity were monitored throughout each sampling date using a sling psychrometer, and vapor pressure deficit (VPD) was calculated from these values. Due to proximity of the upland and lowland sites and similarity of ambient environments, VPD was measured at the upland site only. In 1986, VPD was measured at the upland and riparian sites. Photosynthetic quantum flux density (PFD) was measured with a LI-185 Lambda Quantum Flux Meter (Li-Cor Inc., Lincoln, Neb. ${ }^{1}$ ) at the point where transpiration was measured.

Diurnal values of transpiration, stomatal conductance, VPD, and PFD were pooled to represent mean daily values prior to analysis for the purpose of more readily comparing differences among sites. Data were subjected to general linear model procedure for each year to evaluate date, site, and a date $X$ site interaction as sources of variation. Significantly different means were separated with L.S.D. $(P<0.05)$. Vapor pressure deficit and soil temperature were not replicated and no analyses were performed on these variables.

Mention of trademark or proprietary product does not constitute a guarantee or warranty of the product by Texas Agricultural Experiment Station or Texas Tech University and does not imply approval to the exclusion of other products that may also be suitable.

\section{Results and Discussion}

\section{Climate}

Precipitation was generally above normal from October 1984 through April 1985, prior to the 1985 mesquite growing season (Fig. 1). May and July 1985 had below normal precipitation, but this was an offset somewhat by above normal precipitation in June.

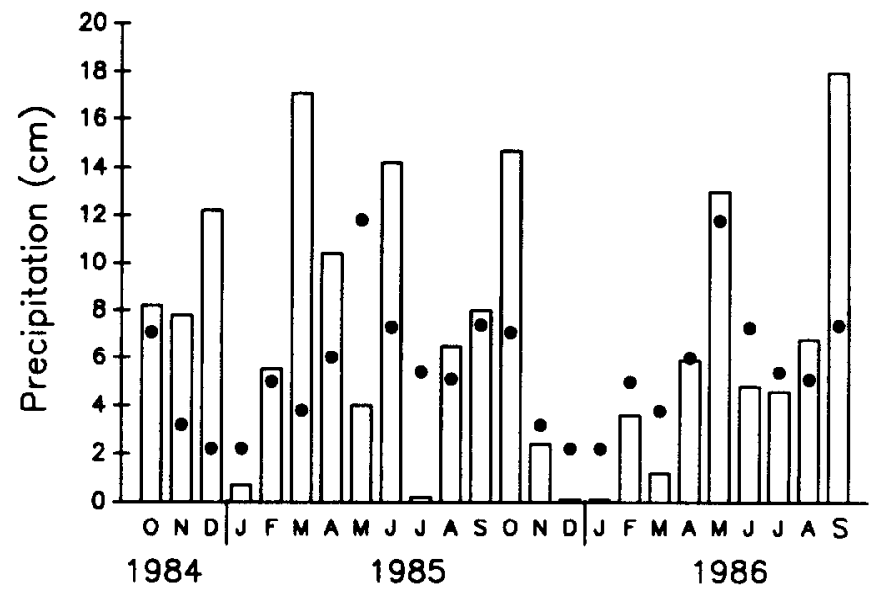

Fig. 1. Monthly precipitation at the study site. Solid circles represent 30-year average precipitation for each month.

Precipitation was below normal from November 1985 until March 1986. After March 1986, rains occurred frequently and monthly totals were near normal. Total precipitation from 1 November to the first sampling date in mid-May of each year was $52.8 \mathrm{~cm}$ and $19.2 \mathrm{~cm}$ in 1985 and 1986 , respectively.

Average daily PFD was greater on the upland than on the lowland site during all sample dates, although on some dates this difference was not significant (Fig. 2). In 1986, average daily PFD
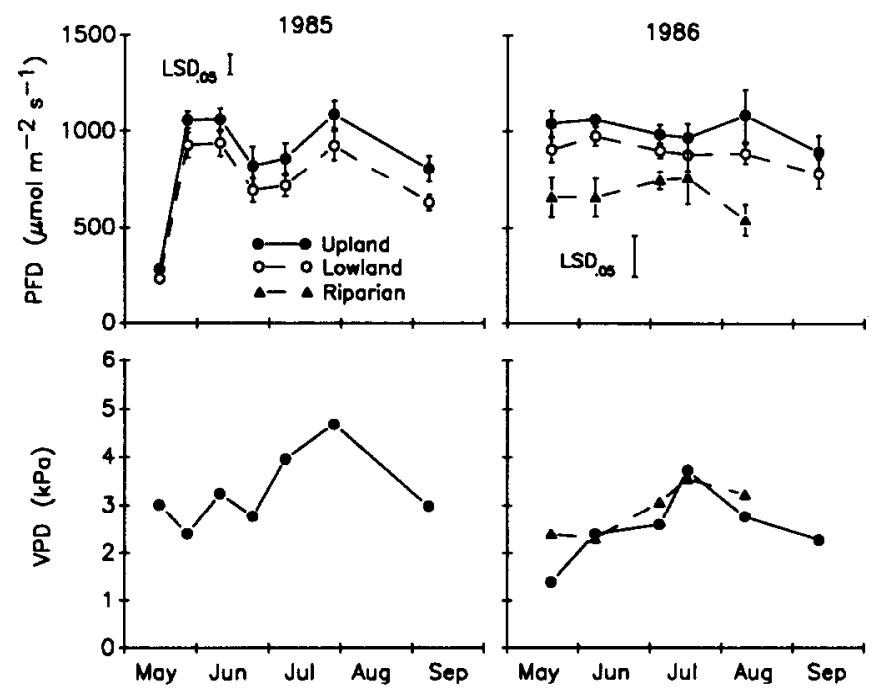

Fig. 2. Average daily photosynthetic fux density (PFD) and average daily vapor pressure deficit (VPD) at each site during 1985 and 1986 (VPD was not recorded on the lowland site). Vertical bars around PFD means are \pm 1 standard error (S.E.).

was lowest on the riparian site, probably because of taller neighboring vegetation on this site which reduced duration of direct sunlight available to mesquite. Diurnally, differences in PFD between sites occurred early and late in the day when shading from neighboring trees was greatest (data not shown). Average daily VPD was lowest in May and June and greatest during July and August of both years. No clear differences in VPD between sites 
were detected in 1986.

\section{Soil Moisture and Temperature}

Volumetric soil water content $(\theta)$ and matric potential were significantly greater at the upland than the lowland site from May through July 1985 (Fig. 3), following rains in March and April which were nearly 3 times the normal amount (Fig. 1). As the 1985 growing season progressed, differences in $\theta$ between the 2 sites diminished (Fig. 3). However, differences in soil matric potential between sites remained significant throughout 1985. Similar differences in $\theta$ and matric potential between the upland and lowland sites were apparent from May to early August 1986. Following
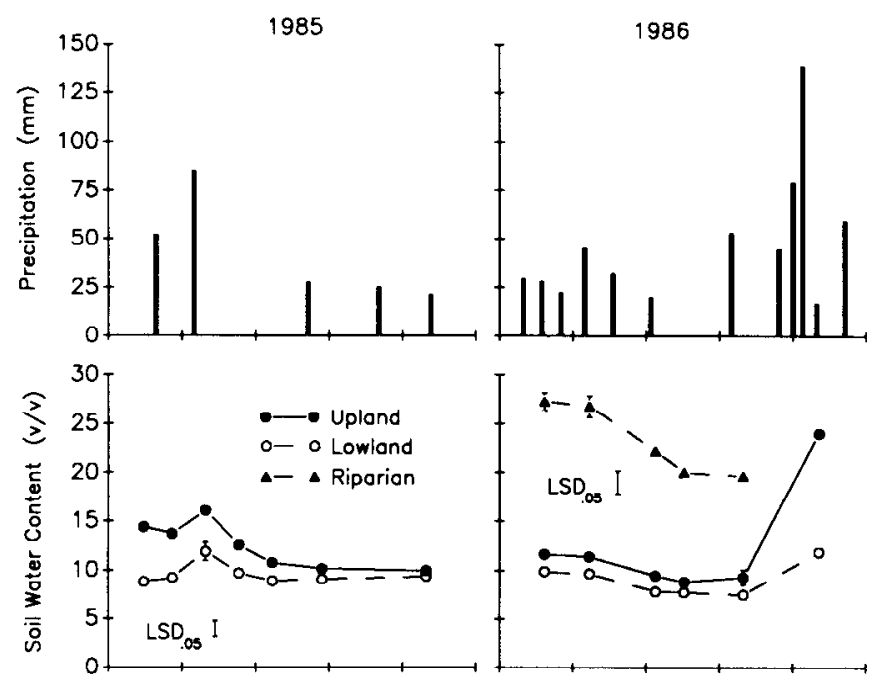

을
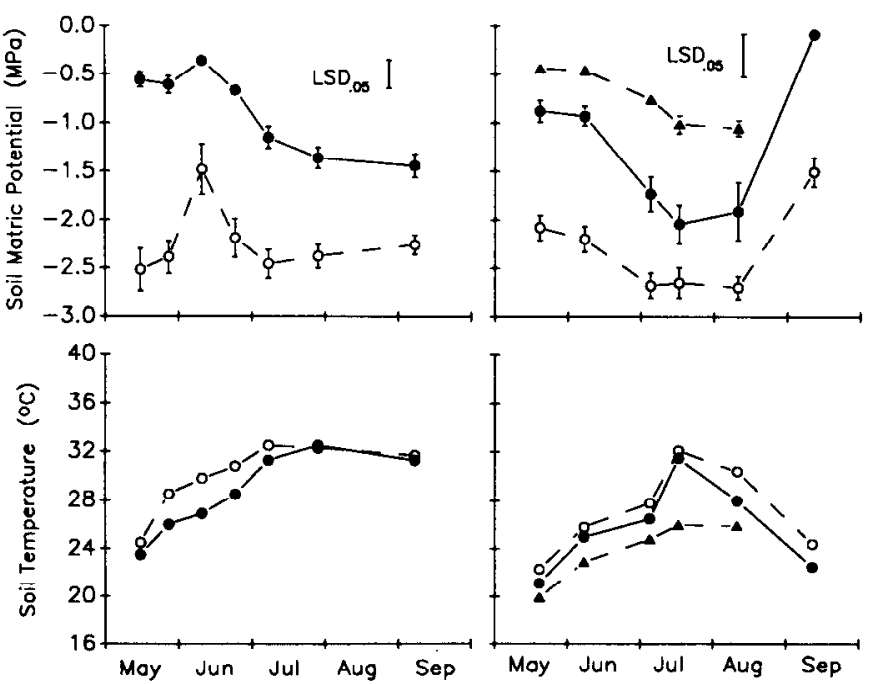

Fig. 3. Individual precipitation events, volumetric soil water content at 30 $+60 \mathrm{~cm}$ depths, soil matric potential at $30+60 \mathrm{~cm}$ depths, and soil temperature at $30 \mathrm{~cm}$ depth on each site during the 1985 and 1986 growing seasons. Vertical bars around each mean indicate \pm 1 S.E. Where not visible, S.E. bars are smaller than mean symbol.

nearly $300 \mathrm{~mm}$ of rain in late August and early September 1986, $\theta$ and soil matric potential increased on both sites, but the increase was greater on the upland than the lowland site, supporting earlier findings that infiltration rates were greater on the upland site.

The riparian site displayed significantly greater $\theta$ and soil matric potential than the other 2 sites in 1986, although differences in matric potential were proportionally less than differences in $\theta$, due to the heavier textured soils on the riparian site. The water table on the riparian site was often within $1.5 \mathrm{~m}$ of the soil surface, as indicated by free standing water in the access tubes.

Soll temperature was greater at the lowland site than the upland site from May through July 1985 and July through September 1986. Soil temperature was consistently lower on the riparian site than on the other sites in 1986. Differences in soil temperature between sites were inversely related to soil water content.

\section{Transpiration and Conductance}

Trees on the upland site exhibited significantly higher average daily transpiration and stomatal conductance than trees on the lowland site during most sample days in 1985 and 1986 (Fig. 4).
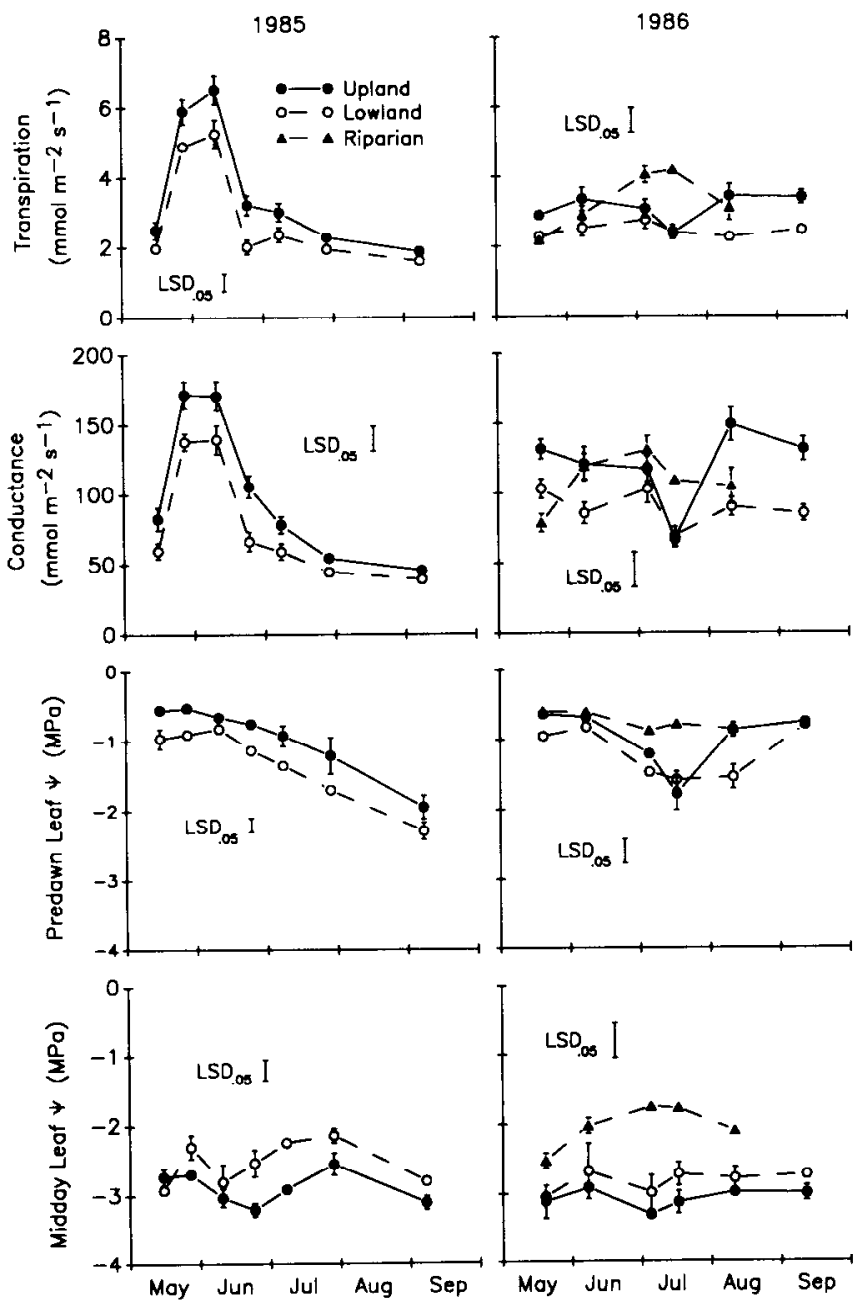

Fig. 4. Average daily transpiration, average daily stomatal conductance, predawn leaf water potential, and midday leaf water potential on each site during the 1985 and 1986 growing seasons. Vertical bars around means indicate \pm S.E.

These results differ from those by Easter and Sosebee (1975) who found in a study near Lubbock, Texas, that transpiration by mesquite was lower on an upland than a lowland site. However, the upland site in their study had less soil moisture than the lowland site, which was opposite our findings. Both studies were in agreement that transpiration by mesquite was greater on sites that had more soil moisture.

As each growing season progressed, transpiration and stomatal conductance declined to similar levels on both the upland and lowland sites by mid- to late-July. Following rains in August and September 1986 (Fig. 3), transpiration and conductance were 
greater on the upland than the lowland site (Fig. 4). Of particular interest was water use by mesquite on 11 August 1986, following a precipitation event of $53 \mathrm{~mm}$ on 5 August (Figs. 3 and 4). Transpiration and conductance increased significantly on the upland site but did not on the lowland site in response to this storm. These results may be an indication that mesquite on the upland site had more shallow, lateral roots to exploit individual precipitation events than trees on the lowland site (Thomas and Sosebee 1978, Heitschmidt et al. 1988, Ansley et al. 1990). Differential responses in transpiration and conductance following the 5 August storm may also be attributed to greater infiltration on the upland site, although soil moisture and matric potential results did not indicate this clearly (Fig. 3),

Mesquite on the riparian site exhibited seasonal patterns of transpiration quite different from the other sites in 1986. During May and early June, transpiration of trees on the riparian site was less than in trees on the upland site and not significantly different from trees on the lowland site. In early and mid-July 1986, when transpiration and conductance were declining on the upland and lowland sites, these variables increased on the riparian site. By mid-July, when VPD was maximum (Fig. 2), average daily transpiration of trees on the riparian site attained a seasonal peak and was $44 \%$ greater than transpiration on the other sites (Fig. 4). Seasonal trends in stomatal conductance among sites were similar to transpiration, although somewhat more variable.

Site related differences in soil temperature may explain why transpiration was lower in the riparian than the upland site at the beginning of the 1986 growing season. Soil temperature was below $24^{\circ} \mathrm{C}\left(75^{\circ} \mathrm{F}\right)$ through June 1986 at the riparian site, but only during May at the upland site (Fig. 3). These differences in soil temperature correspond to the interval when transpiration was lower on the riparian site than on the upland site (Fig. 4). When soil temperature increased to above $24^{\circ} \mathrm{C}$ on all sites (which occurred during all of the 1985 growing season and after June 1986), transpiration was greater on sites that had more soil water, even though differences in soil temperature still existed between sites. Other studies have determined that soil temperatures below $24^{\circ} \mathrm{C}$ inhibit herbicidal control of mesquite (Dahl et al. 1971, Sosebee et al. 1973, Dahl et al. 1978). It has been suggested that soil temperatures below this level inhibit physiological processes in mesquite, which reduce uptake and translocation of herbicides (Meyer 1977, Sosebee 1983). Data from the current study suggest that transpiration may have been reduced when soil temperature was below $24^{\circ} \mathrm{C}$, regardless of soil water content.

A lower average daily PFD on the riparian site in relation to the other sites may also have reduced transpiration on the riparian site. For most species, photosynthetic radiation and transpiration are positively correlated (Schulze and Hall 1982).

\section{Leaf Water Potential}

Predawn leaf water potential (predawn leaf $\Psi$ ) declined from May through September 1985 and May through July 1986 in trees on the upland and lowland sites (Fig. 4). Predawn leaf $\Psi$ was significantly greater in trees on the upland site than on the lowland site throughout 1985 and on certain dates in 1986. Similar to transpiration and conductance, predawn leaf $\Psi$ increased to a greater degree in upland than lowland trees following rains in August and September 1986. Seasonal differences in predawn leaf $\Psi$ between the upland and lowland sites paralleled responses of transpiration and soil water content and suggest a direct positive relationship between the 3 variables. Ansley et al. (1992) found similar relationships between predawn leaf $\Psi$, transpiration, and soil water content when mesquite trees were subjected to irrigation and rain-sheltering.
Mesquite on the riparian site expressed a seasonally stable predawn leaf $\Psi$ in 1986, which was greater on most dates than in trees on the other 2 sites (Fig. 4). Differences in predawn leaf $\Psi$ between the riparian site and the other 2 sites increased as the 1986 growing season progressed until August.

Midday leaf $\Psi$ was greater in trees on the lowland site than in trees on the upland site.on most dates in 1985 (Fig. 4). An inverse relationship was expressed between midday leaf $\Psi$ and transpiration or predawn leaf $\Psi$ in which midday leaf $\Psi$ was lower in the trees that had greater transpiration and predawn leaf $\Psi$. These results concur with Ansley et al. (1990) who found that a lower midday leaf $\Psi$ was an indication of more, not less, water movement through the soil-plant atmosphere continuum in non-phreatophytic mesquite. Midday leaf $\Psi$ was significantly greater in trees on the riparian site than on other sites in 1986 . Thus, when soil water was unlimiting, as on the riparian site, midday leaf $\Psi$ appeared to be positively correlated with transpiration and predawn leaf $\Psi$.

\section{Summary and Management Implications}

In summary, soil water content was the primary environmental factor which influenced mesquite transpiration on all 3 sites. Vapor pressure deficit has been reported to have a strong influence on honey mesquite transpiration (Wendt et al. 1968). However, we did not find consistent differences in VPD between sites and VPD could not explain the variation in transpiration between sites.

We expected transpiration to be greater on the lowland than the upland site because of the relative positions of the 2 sites within the watershed, and because the lowland site had deeper soils. However, soil water content and transpiration were consistently greater on the upland than the lowland site. These results were attributed to textural differences at the soil surface between the sites which provided greater infiltration on the upland site.

Transpiration on the upland site was influenced strongly by precipitation, suggesting mesquite relied on shallow roots to obtain moisture near the surface. With lower infiltration, trees on the lowland site may have depended on deeper roots to express a more consistent, although generally lower, seasonal water use pattern than trees on the upland site. The riparian site had a much greater volumetric water content than the other sites but considerably heavier soil texture on this site may have limited water availability. As a result, while transpiration was greatest on this site during mid-summer 1986, it never exceeded maximum values attained by trees on the other 2 sites in the previous year. Transpiration was suppressed on the riparian site in relation to the other sites during May and June 1986, which may have been caused by lower soil temperature on the riparian site.

Adjustment of internal water status during the overnight recharge period was facilitated by more soil water. This was reflected by greater predawn leaf $\Psi$ in trees on the upland site, which had more soil water, than on the lowland site. Midday leaf $\Psi$, however, was inversely related to predawn leaf $\Psi$ and transpiration on these 2 sites. When water was not limiting, as on the riparian site, predawn leaf $\Psi$, midday leaf $\Psi$, and transpiration were positively correlated.

Results from this study suggest that water use by honey mesquite is not directly related to the topographical position of these plants within a watershed. Therefore, efforts to increase water yield through reduction of mesquite should consider site characteristics, especially those capable of high infiltration, before selecting areas to be treated. Similarly, managers attempting to control mesquite on the basis of hypothesized physiological activity of the plant, as when spraying foliar applied herbicides, should be cognizant of the fact that trees on lower sites with deeper soils may not necessarily be more active than those on shallow sites. 


\section{Literature Cited}

Ansley, R.J., P.W. Jacoby, and G.J. Cuomo. 1990. Water relations of honey mesquite following severing of lateral roots: Influence of location and amount of subsurface water. J. Range Manage. 43:436-442.

Ansley, R.J., P.W. Jacoby, and B.K. Lawrence. 1992. Response of differentially water-stressed honey mesquite to watering. J. Arid Environ. (In Press).

Bouyoucos, G.J. 1936. Directions for making mechanical analysis of soils by the hydrometer method. Soil Sci. 42:225-228.

Cable, D.R. 1977. Seasonal use of soil water by mature velvet mesquite. J. Range Manage. 30:4-11.

Dahl, B.E., R.B. Wadley, M.R. George, and J.L. Talbot. 1971. Influence of site on mesquite mortality from 2,4,5-T. J. Range Manage. 24:210-215.

Dahl, B.E., R.E. Sosebee, J.P. Goen, and C.S. Brumley. 1978. Will mesquite control with 2,4,5-T enhance forage production? J. Range Manage. 31:129-131.

Easter, S.J., and R.E. Sosebee. 1975. Influence of soil-water potential on the water relationships of honey mesquite. J. Range Manage. 28:230-232.

Heitschmidt, R.K., R.J. Ansley, S.L. Dowhower, P.W. Jacoby, and D.L. Price. 1988. Some observations from the excavation of honey mesquite root systems. J. Range Manage. 41:227-231.

Koos, W.M., J.C. Williams, and M.L. Dixon. 1962. Soil survey of Wilbarger County, Texas. USDA Soil Conserv. Serv., Soil Surv. Ser. 1959 No. 18, Fort Worth, Tex.

Ludwig, J.A. 1977. Distributional adaptations of root systems in desert environments. p. 85-91. In: J.K. Marshall (eds.). The below ground ecosystem: A synthesis of plant associated processes. Range Sci. Dept. Ser. 26, Colorado State Univ., Fort, Collins, Colo.
Meyer, R.E. 1977. Seasonal response of honey mesquite to herbicides. Texas Agr. Exp. Sta. Bull. 1174. College Sta.

Mooney, H.A., B.B. Simpson, and O.T. Solbrig. 1977. Phenology, morphology, physiology, p. 26-43. In: B.B. Simpson (ed.), Mesquite, its biology in two desert shrub ecosystems. Halsted Press. N.Y.

Nilsen, E.T., P.W. Rundel, and M.R. Shariff. 1981. Summer water relations of the desert phreatophyte Prosopis glandulosa in the Sonoran Desert of Southern California. Decologia 50:271-276.

Phillips, W.S. 1963. Depths of roots in soil. Ecology 44:424.

Richards, L.A. 1965. Physical condition of water in soil. p. 128-152. In: Methods of Soil Analysis. Amer. Soc. Agron. Monogr. 9.

Scholander, P.F., H.T. Hammel, E.D. Bradstreet, and E.A. Hammingsen. 1965. Sap pressure in vascular plants. Negative hydrostatic pressure can be measured in plants. Science 148:339-346.

Schulze, E.D., and A.E. Hall. 1982. Stomatal responses, water loss and $\mathrm{CO}_{2}$ assimilation rates of plants in contrasting environments. Chap. 7, p. 181-224. In: O.L. Lange et al. (eds.) Physiological Plant Ecology II, Vol. 12B. Encyclopedia of Plant Physiology, Springer Verlag, Berlin.

Scifres, C.J. 1980. Brush management. Texas A\&M Univ. Press. College Station.

Sosebee, R.E., B.E. Dahl, and J.P. Goen. 1973. Factors affecting mesquite control with Tordon 225 mixture. J. Range Manage. 26:369-371.

Sosebee, R.E. 1983. Physiological, phenological, and environmental considerations in brush and weed control, p. 27-43. In: McDaniel, K.C. (ed.) Proc. Brush Management Symp. Soc. Range Manage. 36th Annu. Meeting, 16 Feb. 1983, Albuquerque, N.M.

Thomas, G.W., and R.E. Sosebee. 1978. Water relations of honey mesquite-A facultative phreatophyte. p. 414-418. In: D.N. Hyder (ed.). Proc. 1st Int. Rangeland Congress. Denver, Colo.

Wendt, C.W., R.H. Haas, and J.R. Runkles. 1968. Influence of selected environmental variables on the transpiration rate of honey mesquite [(Prosopis glandulosa var. glandulosa (Torr.) Cockr.]. Agron. J. 60:382-384. 